\title{
Program Kemitraan Masyarakat Home Industry Kacang Sangrai Desa Cisoka Kabupaten Tangerang
}

\author{
Yudhi Chandra Dwiaji ${ }^{1 *}$; Niken Sulistyowati ${ }^{2}$ \\ Published online: 5 July 2021
}

\begin{abstract}
The purpose of this service is to provide training and knowledge to partners in using appropriate technology so that the productivity and efficiency of the Cisoka's roasted bean craftsmen's activities increases. The method used in this activity is participatory and collaborative methods where partners participate in activities such as socialization and training, operation and maintenance of roasting machines and packaging sealer machines.
\end{abstract}

Keyword: Cisoka, roasted bean, packaging

\begin{abstract}
Abstrak: Tujuan pelaksanaan pengabdian ini adalah untuk memberikan pelatihan dan pengetahuan kepada mitra dalam penggunaan TTG agar produktivitas dan efisiensi kegiatan pengrajin kacang sangrai Cisoka meningkat. Metode yang digunakan dalam kegiatan ini adalah metode parsipatori dan kolaboratif dimana mitra ikut berpartisipasi dalam kegiatan seperti sosialisasi dan pelatihan, pengoperasian dan pemeliharaan mesin sangrai dan mesin sealer kemasan.
\end{abstract}

Kata kunci: Cisoka, kacang sangrai, pengemasan

\section{PENDAHULUAN}

Desa Cisoka terletak di Kecamatan Cisoka, Kabupaten Tangerang dengan luas wilayah sebesar 283,5 ha (BPS, 2016). Di sebelah utara berbatasan dengan Desa Caringin. Bagian barat berbatasan dengan Desa Sukatani dan Desa Bojongloa. Bagian timur berbatasan dengan Desa Jeunjing, sedangkan di sebelah selatan berbatasan dengan Desa Sukatani dan Desa Pesanggrahan Kecamatan Solear. Desa Cisoka merupakan desa yang berjarak terbilang dekat dengan Kota Tangerang. Selain itu, Desa Cisoka memiliki potensi dalam hal tempat wisata karena memiliki Telaga Biru yang menjadi daya tarik. Kondisi geografisnya sangat mendukung untuk menjadi Desa Cisoka sebagai tempat wisata.

Kacang tanah merupakan tanaman pangan yang mempunyai nilai ekonomi tinggi karena kandungan gizinya terutama protein dan lemak yang tinggi. Kebutuhan kacang tanah dari tahun ke tahun terus meningkat sejalan dengan bertambahnya jumlah penduduk, kebutuhan gizi masyarakat, diversifikasi pangan, serta meningkatnya kapasitas industri pakan dan makanan di Indonesia. Namun

1,2 Universitas Mercu Buana

*) corresponding author

Yudhi Chandra Dwiaji

Program Studi Teknik Mesin, Fakultas Teknik

Universitas Mercu Buana, Jakarta, Indonesia

Email: yudhichandra7@gmail.com produksi kacang tanah dalam negeri belum mencukupi kebutuhan Indonesia yang masih memerlukan subsitusi impor dari luar negeri (Sembiring, et al. 2014). Masyarakat pada saat ini harus memiliki pemikiran dan tujuan yang sama yaitu untuk memikul tanggung jawab bersama agar produk pertanian yang di jual atau di eksport tidak hanya secara langsung dijual melainkan dilakukan 
pengelolahan produk terlebih dahulu sehingga memiliki nilai tambah (Anonim 1, 2012). Produksi tanaman kacang tanah nasional sejak tahun 2012 terus mengalami penurunan. Tahun 2012 produksi tanaman kacang tanah nasional sebesar 559.538 ton dan terus menurun setiap tahun. Tahun 2015 produksi tanaman kacang tanah sebesar 454.063 ton (BPS, 2016) sedangkan rata-rata kebutuhan kacang tanah nasional setiap tahun sebesar \pm 816 ribu ton biji kering (Kementan, 2016).

Kacang sangrai Cisoka merupakan salah satu oleh-oleh khas kabupaten Tangerang dan menjadi sumber pendapatan utama bagi mitra. Kacang tanah yang diolah menjadi kacang sangrai dimanfaat oleh mitra yaitu keluarga bapak Baning sebagai usaha rumah tangga sejak tahun 1970-an. Kacang sangrai Cisoka ini cukup digemari oleh para konsumen selain rasanya yang gurih, kacang sangrai ini memiliki tekstur yang lebih renyah dan rasa yang khas bila dibandingkan kacang sangrai/goreng sejenisnya. Namun seiring bergesernya waktu, usaha kacang sangrai rupanya kian lama kian tergerus oleh perubahan jaman, dimana home industry ini hanya tinggal sedikit. Dari penuturan warga desa Cisoka, di wilayah ini hanya tinggal 2 pengrajin kacang sangrai saja yang masih bertahan hidup.

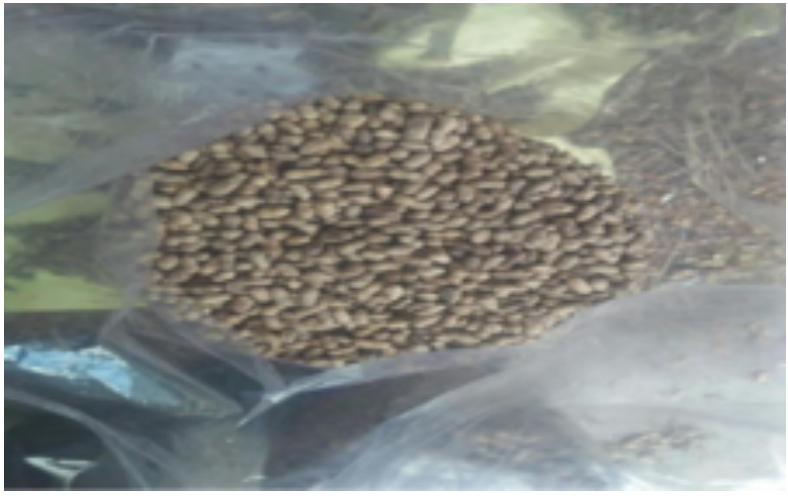

(a)

Gambar 1. (a) Kacang sangrai Cisoka.

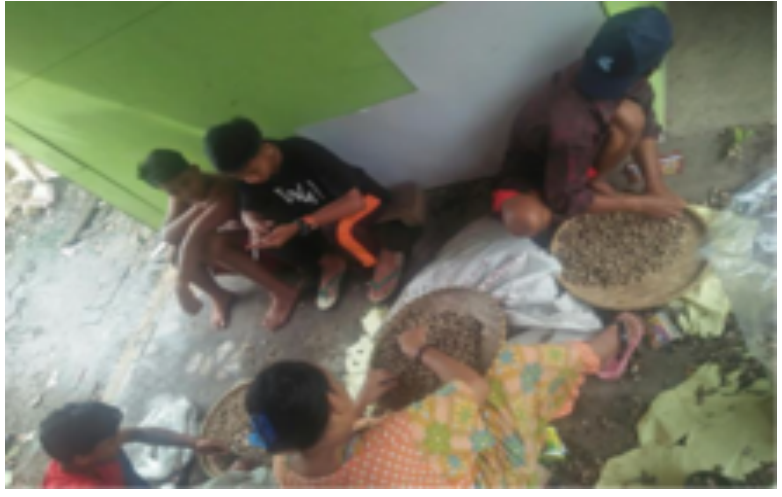

(b)

(b) Kegiatan mitra memilah kacang yang baik

Permasalahan utama mitra adalah saat melakukan proses produksi ternyata masih menggunakan secara tradisional / secara manual. Hal ini tentu cukup memberatkan bagi mitra untuk memproduksi kacang sangrai dalam jumlah besar. Sehingga secara teknis tentunya kurang efisien dalam proses pembuatan kacang sangrai tersebut. Untuk memproduksi barang dalam jumlah yang banyak, diperlukan suatu alat yang dapat membantu dan mempercepat proses produksi tersebut yakni mesin (Dwiaji, 2016). Disamping itu dari sisi pengemasan (packaging) kacang tersebut dirasa kurang menarik. Padahal, dengan ada kemasan, konsumen mendapat layanan dalam menyelamatkan barang yang dibeli dan mempunyai jaminan yang ada kepuasan tersendiri dari barang produk yang akan menjadi milik dirinya, yang akhirnya terselamatkan dari hal yang tidak diharapkan selama di perjalanan sampai tujuan (Mukhtar, 2016).

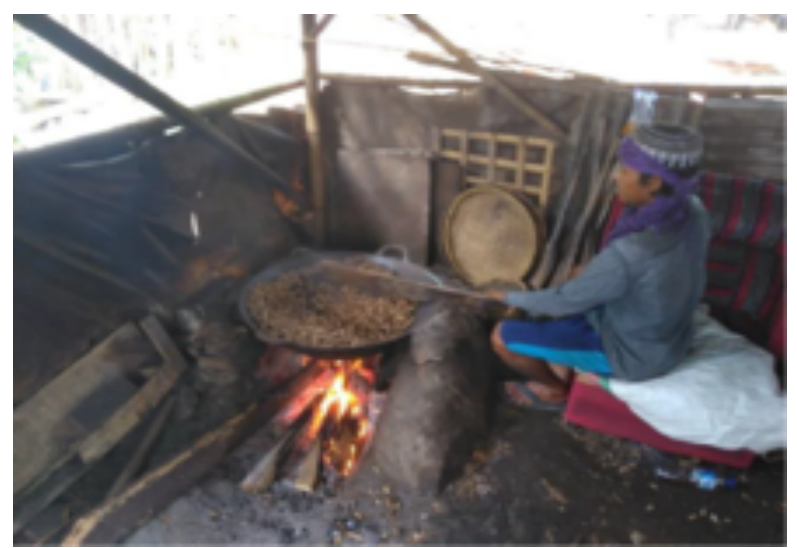

(a)

Gambar 2. (a) Mitra melakukan kegiatan produksi.

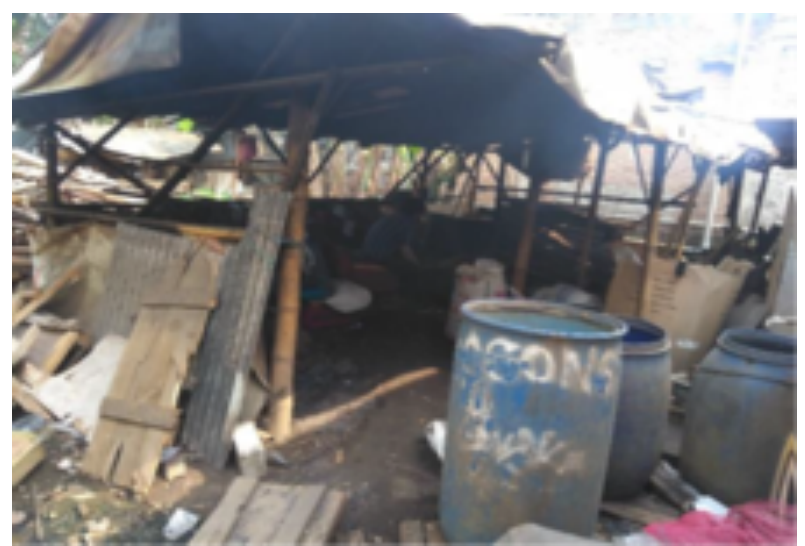

(b)

(b) Tempat produksi kacang Cisoka 
Tujuan kegiatan Pengabdian Kepada Masyarakat ini adalah untuk meningkatkan kuantitas dan kualitas kacang sangrai Cisoka yang diolah oleh mitra. Hal ini dilakukan dengan cara pembuatan mesin sangrai kacang yang diiringi bertambahnya kecepatan proses peningkatan kemampuan sumber daya manusia sesuai dengan laju pertumbuhan pembangunan di desa tersebut. Peningkatan SDM dapat juga dilakukan melalui pemberian ilmu pengetahuan supaya masyarakat menjadi lebih terampil dalam berbagai hal (Desnelita, 2019). Hal ini berkenaan dengan upaya untuk memberikan motivasi, semangat dan keterampilan kepada mitra untuk mengembangkan potensi yang ada di daerahnya dengan mengelola hasil pertanian menjadi bisnis kewirausahaan dengan pengembangan pada produk utamanya (Dwiaji, 2018). Harapannya adalah bertambahnya kecepatan upaya pengembangan mitra ke arah terbinanya masyarakat yang harmonis serta dinamis yang siap menempuh perubahanperubahan menuju perbaikan dan kemajuan sesuai dengan nilai-nilai sosial budaya dan norma-norma dalam kehidupan masyarakat berkembang dalam kehidupan masyarakat yang berlaku. Dan juga untuk memperoleh umpan balik dan masukan bagi fakultas dan Universitas Mercu Buana dalam rangka meningkatkan relevansi pendidikan, diperlukan adanya ahli-ahli yang memiliki kemampuan secara interdisipliner dan multidisipliner.

\section{BAHAN DAN METODE}

Metode yang digunakan pada kegiatan ini adalah metode partispatori. Keberhasilan kegiatan ini dengan menggunakan metode partisipatori sangat ditentukan oleh partisipasi dari mitra pada kegiatan. Hal ini sesuai dengan pendapat (Sholeh, 2011), metode adalah jalan yang harus dilalui untuk mencapai tujuan. (Agung, 2012) menyatakan bahwa metode partisipatori adalah upaya untuk melibatkan partisipasi baik itu pihak-pihak yang berada di lingkungan organisasi itu maupun pihak yang berada di luar organisasi. Mitra akan dilibatkan secara langsung dalam kegiatan ini mulai dari proses sosialisasi dan pelatihan mitra, termasuk juga didalamnya pemeliharaan. Tahapan metode parsipatori yang akan dilakukan dalam kegiatan ini adalah:

1. Melakukan pertemuan dengan lurah dan mitra,

2. Melakukan sosialisasi dan wawancara dengan mitra mengenai prioritas permasalahan dalam usahanya dan memberikan pengarahan agar mereka ikut berpartisipasi dalam kegiatan ini.

Untuk mencapai tujuan dari kegiatan ini, harus mendapat dukungan dari pemerintah setempat dengan melakukan kerja sama. Adapun tahapan pelaksanaan kegiatan ini adalah perencanaan, sosialisasi dan pelatihan, pembuatan mesin sangrai kacang, dan pemeliharaan sebagai berikut:

1. Perencanaan

Perencanaan pembuatan mesin sangrai kacang yang akan dilakukan dengan memperhatikan pemilihan teknologi yang tepat untuk diterapkan pada mitra. Pemilihan teknologinya berdasarkan kualitas dan kuantitas kacang sangrai yang dihasilkan. Pemilihan teknologi harus murah, mudah didapat, tidak beracun, serta aman bagi manusia dan lingkungan. Selain itu material yang digunakan untuk mesin murah, mudah dikelola dan dirawat. Serta teknologi ini mudah diterapkan dan digunakan oleh mitra. Selain itu, mesin sangrai kacang yang dirancang mampu meningkatkan produktivitas usaha kacang Cisoka khas kabupaten Tangerang. Mesin sangrai kacang yang dibuat memiliki kapasitas 20-30 kg/proses. Mesin yang dibuat mudah dalam hal pengoperasian dan pemeliharaan oleh mitra, didukung oleh SOP yang akan diberikan kepada mitra sebagai acuan dalam pengelolaan dan pemeliharaan mesin sangrai kacang.

2. Sosialisasi dan pelatihan

Kegiatan ini dilakukan melalui pertemuan dengan mitra dalam bentuk sosialisasi dan pelatihan. Kegiatan awal yang dilakukan berupa diskusi dan sosialisasi terkait permasalahan dalam mitra terkait kendala yang telah dijelaskan yaitu penggunaan teknologi dan perbaikan sanitasi tempat usaha. Setelah itu dilakukan pelatihan cara penggunaan dan pemeliharaan mesin sangrai kacang dan mesin sealer kemasan. 
Partisipasi mitra dalam kegiatan PKM ditunjukkan dengan adanya dukungan baik material dan kesanggupan kerja sama sebagai mitra dengan tim dari Universitas Mercu Buana (UMB) dalam penerapan teknologi mesin sangrai kacang dan mesin sealer kemasan. Partisipasi mitra ini ditunjukkan melalui pelaksanaan kegiatan secara bersama-sama dalam kegiatan sosialisasi dan pelatihan mitra terkait cara penggunaan dan pemeliharaan mesin tersebut;

3. Pembuatan Mesin Sangrai Kacang Tanah

Pembuatan mesin sangrai kacang menerapkan prinsip mudah dikelola dan dirawat. Sedangkan untuk penerapan GMP diperlukan SOP yang sesuai dimana kelompok mitra diberikan pengarahan mengenai tata letak dan perawatan peralatan untuk menjamin kelayakan proses produksi melalui berbagai analisa teknis dan ekonomis. Tentunya dengan memberikan penyuluhan untuk mencegah berbagai faktor yang mungkin dapat menyebabkan timbulnya pencemaran bagi produk dan lingkungan.

\section{HASIL DAN PEMBAHASAN}

Pengabdian kepada masyarakat adalah usaha untuk menyebarluaskan ilmu pengetahuan, teknologi, dan seni kepada masyarakat. Kegiatan tersebut harus mampu memberikan suatu nilai tambah bagi masyarakat, baik dalam kegiatan ekonomi, kebijakan, dan perubahan perilaku (sosial). Uraikan bahwa kegiatan pengabdian telah mampu memberi perubahan bagi individu/masyarakat maupun institusi baik jangka pendek maupun jangka panjang. Adapun tahapan pelaksanaan kegiatan ini adalah perencanaan, pembuatan mesin sangrai kacang tanah, sosialisasi dan pelatihan.

1. Perencanaan dan pembuatan mesin sangrai

Perencanaan pembuatan mesin sangrai kacang tanah yang akan dilakukan dengan memperhatikan pemilihan teknologi yang tepat untuk diterapkan pada mitra. Pemilihan teknologinya berdasarkan kualitas dan kuantitas kacang sangrai yang dihasilkan.

Pemilihan teknologi sebaiknya yang dapat dipakai dalam jangka panjang, juga bahan mudah didapat, tidak beracun, serta aman bagi manusia dan lingkungan. Mesin setidaknya menggunakan teknologi yang mudah dikelola dan dirawat. Serta teknologi ini mudah diterapkan dan digunakan oleh mitra. Selain itu, mesin sangrai kacang tanah ini dirancang mampu meningkatkan produktivitas usaha mitra. Mesin yang dibuat mudah dalam hal pengoperasian dan pemeliharaan oleh mitra, didukung oleh SOP yang akan diberikan kepada mitra sebagai acuan dalam pengelolaan dan pemeliharaan mesin sangrai kacang tanah. Pembuatan mesin sangrai kacang menerapkan prinsip mudah dikelola dan dirawat. Adapun proses pembuatan mesin sangrai kacang tanah dapat dilihat pada gambar dibawah.

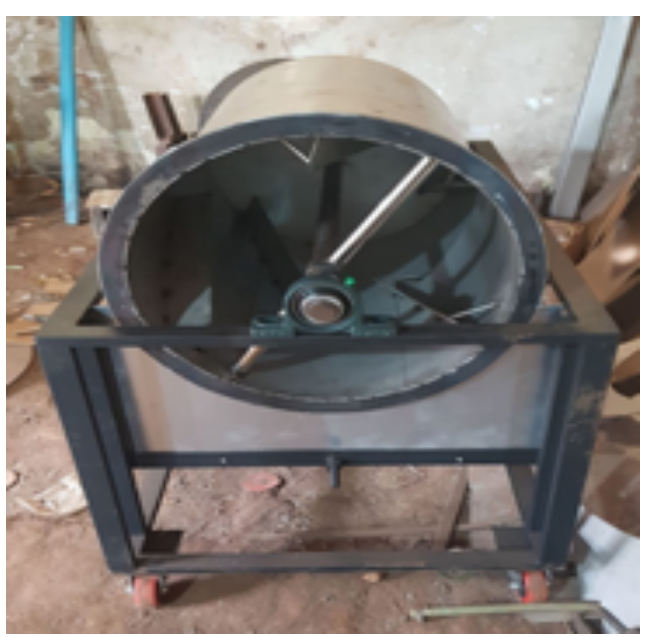

(a)

Gambar 3. (a) Proses pembuatan mesin sangrai.

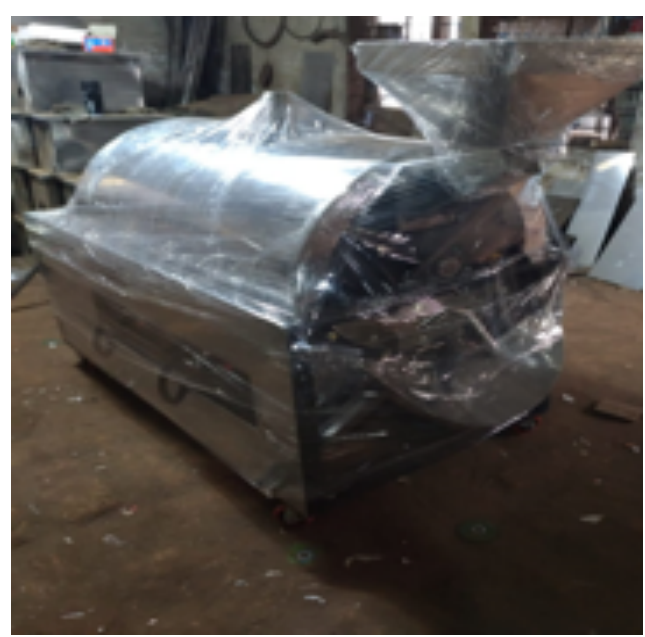

(b)

(b) Mesin sangrai siap pakai 
2. Sosialisasi dan Pelatihan

Kegiatan ini dilakukan melalui pertemuan dengan perwakilan UKM Baning dalam bentuk sosialisasi dan pelatihan. Kegiatan awal yang dilakukan berupa diskusi dan sosialisasi terkait permasalahan dalam UKM terkait kendala dan teknologi yang tepat. Setelah itu dilakukan pelatihan cara penggunaan dan pemeliharaan mesin sangrai kacang tanah serta pelatihan pengemasan kacang sangrai.

Kegiatan Program Kemitraan Masyarakat (PKM) ini dilaksanakan di UKM Baning Desa Cisoka Kecamatan Cisoka Kabupaten Tangerang pada tanggal 10 Juli 2020. Kegiatan PKM berjalan dengan lancar. Hal ini dilihat dari respon positif yang diberikan oleh mitra terkait teknologi tepat guna mesin kacang sangrai. Mitra juga berpartisipasi aktif dalam kegiatan perencanaan, sosialisasi dan pelatihan.

Komunikasi yang baik dan lancar dengan mitra merupakan kunci utama dalam keberhasilan dan kemudahan pelaksanaan kegiatan PKM ini. Adapun materi yang disampaikan pada kegiatan sosialisasi dan pelatihan adalah:

a. Teknologi tepat guna mesin sangrai kacang tanah

b. Tata cara penggunaan (operasional) dan pemeliharaan mesin sangrai kacang tanah

Partisipasi mitra dalam kegiatan PKM ditunjukkan dengan adanya dukungan berupa kesanggupan kerja sama sebagai mitra dengan tim dari Universitas Mercu Buana (UMB) dalam penerapan teknologi mesin sangrai kacang tanah. Partisipasi mitra ini ditunjukkan melalui pelaksanaan kegiatan secara bersama-sama dalam kegiatan sosialisasi dan pelatihan kelompok mitra terkait cara penggunaan dan pemeliharaan mesin sangrai kacang tanah; dan pembuatan kacang sangrai yang baik.

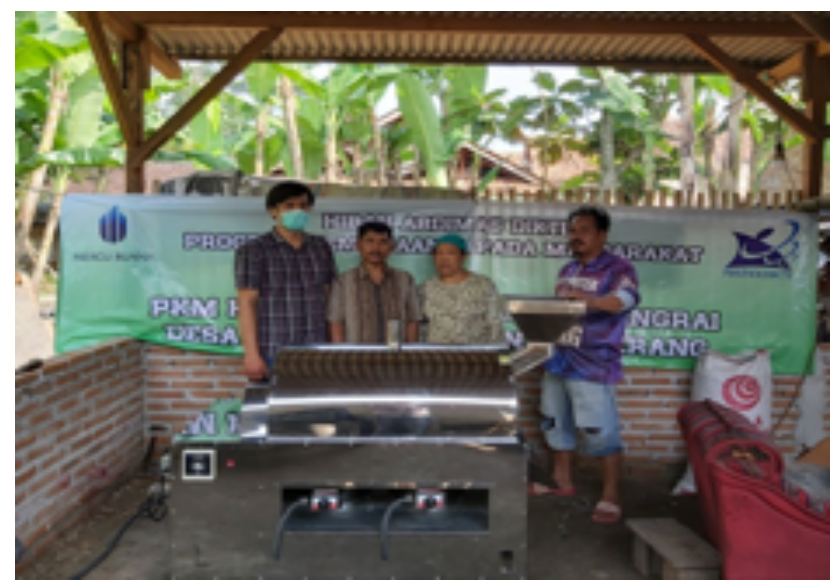

Gambar 4. Mitra dan tim pelaksana berswafoto didepan mesin sangrai kacang

\section{Produk Kegiatan PKM}

Produk dari kegiatan PKM adalah mesin sangrai kacang tanah yang mudah digunakan dan dipelihara oleh mitra, serta aman untuk dimanfaatkan oleh mitra. Mesin sangrai kacang tanah ini bertujuan untuk mempercepat dalam proses sangrai kacang tanah dalam jumlah yang besar. Kacang sangrai yang sudah diolah dijual oleh mitra untuk meningkatkan taraf hidup dan kesejahteraan masyarakat.

Sedangkan mesin sealer plastik bertujuan untuk mempermudah pengemasan dan penjualan produk agar lebih dapat menjangkau di luar wilayah Cisoka. Produk yang dikemas dengan baik tentunya akan menambah daya jual dan daya saing dalam pasar. Sehingga dengan adanya mesin ini dan kegiatan pelatihan pengemasan mandiri dapat membuka peluang usaha dan meningkatkan kesejahteraan masyarakat. 


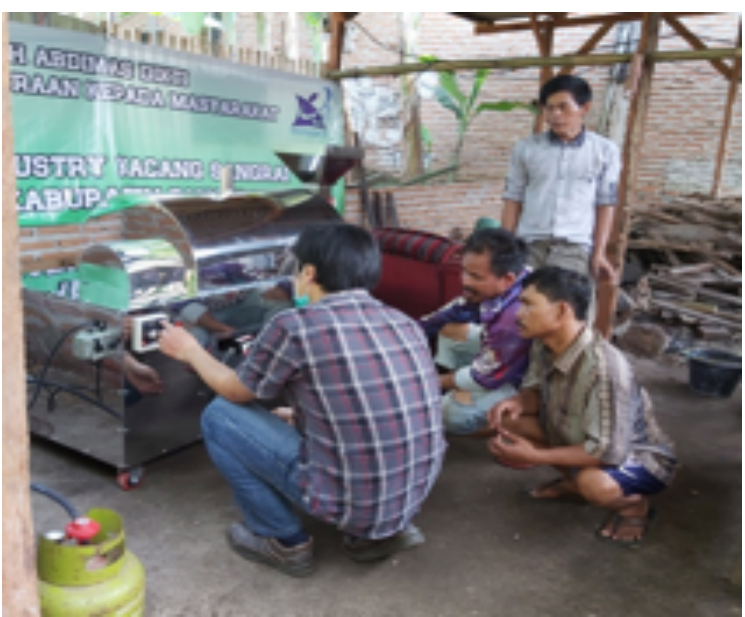

(a)

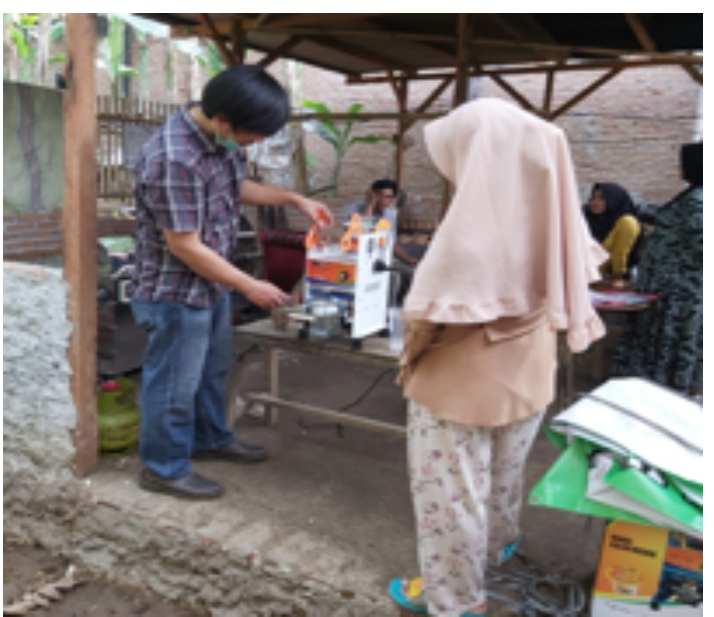

(b)

Gambar 5. (a) Tim pelaksana memberikan pelatihan penggunaan mesin sangrai. (b) Tim pelaksana memberikan pengenalan mesin sealer kepada mitra

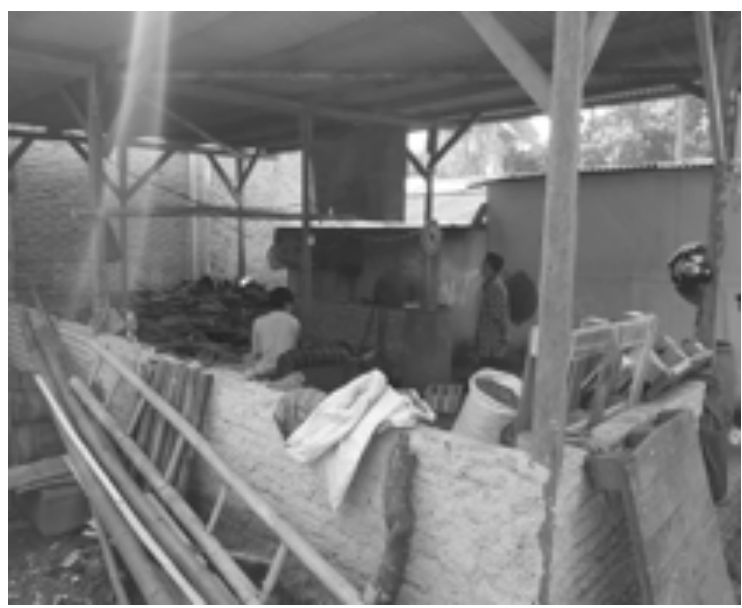

Gambar 6. Perbaikan tempat produksi kacang sangrai

Perbaikan tempat produksi kacang sangrai juga dilakukan oleh tim pelaksana agar tempat tersebut menjadi layak bagi mitra. Disamping itu sirkulasi udara yang baik akan membantu mitra dalam memproduksi kacang sangrai dengan nyaman.

\section{KESIMPULAN DAN SARAN}

Dari kegiatan pengabdian pada masyarakat ini dapat disimpulkan bahwa:

1. Pengetahuan dan pemahaman mitra menjadi meningkat dimana sebelumnya tidak mengetahui adanya teknologi tepat guna untuk mensangrai kacang tanah

2. Pengalaman dan keterampilan baru yang didapat mitra terhadap cara mengemas dan mensangrai kacang.

Mengingat besarnya manfaat kegiatan pengabdian pada masyarakat ini, maka selanjutnya perlu:

1. Mengadakan monitoring berkelanjutan serupa kepada mitra, dengan materi yang sama.

Adanya kesinambungan pasca kegiatan pengabdian ini baik dari pengabdi, pemerintah setempat dan mitra sehingga ada kolaborasi yang baik. 


\section{UCAPAN TERIMAKASIH}

Penulis ingin mengucapkan rasa syukur kepada Allah Swt. karena telah memberikan rahmat dan nimatnya, terutama nikamat sehat dan sempat sehingga Penulis bisa menyelesaikan artikel ini. Penulis juga tidak lupa menyampaikan terimakasih kepada keluarga atas dukungan dan doanya.

\section{Conflict of Interests}

The authors declared that no potential conflicts of interests with respect to the authorship and publication of this article.

\section{DAFTAR PUSTAKA}

Agung, Iskandar. (2012). Strategi Mengembangkan Organisasi Pembelajar di Sekolah. Jakarta: Bee Media Indonesia.

Anonimous 1. (2012). Kajian Nilai Tambah Produk Pertanian. Kementrian Keuangan Republik Indonesia Badan Kebijakan Fiskal. Pusat Kebijakan Ekonomi Makro, Jakarta.

Badan Pusat Statistik. (2016). Data Produksi Kacang Tanah. Online: www.bps.go.id diakses pada tanggal 12 September 2020.

Desnelita, Y., Gustientiedina, G., Susanti, W., Nasien, D., \& Noratama Putri, R. (2019). PKMS PELATIHAN DESAIN GRAFIS MENUJU WIRAUSAHA BAGI PEMUDA RT.03 RW.04 KELURAHAN UMBAN SARI. Dinamisia: Jurnal Pengabdian Kepada Masyarakat, 3(2), 266272. https://doi.org/10.31849/dinamisia.v3i2.3662

Kementrian Pertanian (2016). Petunjuk Teknis Pengelolaan Produksi Kacang Tanah dan Kacang Hijau Tahun Anggaran 2016. Kementrian Pertanian: Direktorat Jenderal Tanaman Pangan.

Sembiring, M., R. Sipayung, dan F. E. Sitepu. (2014). Pertumbuhan dan Produksi Kacang Tanah dengan Pemberian Kompos Tandan Kosong Kelapa Sawit Pada Frekuensi Pembumbunan yang Berbeda. J. Online Agroekoteknologi, 2(2): 598- 607.

Sholeh, Hamid. (2011). Metode Edutainment. Yogyakarta: Diva Press.

Syukron, HS, Lisa Mawarni, T. Irmansyah. (2017). Pertumbuhan dan Produksi Kacang Tanah (Arachis hypogea L.) Dengan Beberapa Sistem Olah Tanah dan dan Asosiasi Mikroba. Jurnal Agroekoteknologi FP USU, Vol.5. No.1, Januari 2017 (26): 202-207

Dwiaji, Yudhi Chandra. (2016) Pengukuran Keefektifan Keseluruhan Peralatan (Oee) sebagai Upaya Meningkatkan Nilai Efektivitas Mesin Blowing. Jurnal Teknik Mesin Mercu Buana, 5 (4), $143-$ 145. http://dx.doi.org/10.22441/jtm.v5i4.1218

Dwiaji, Y.C., N. Nurato, B. Hanum (2018). Kegiatan Iptek bagi Masyarakat (IBM) Karang Taruna dan PKK Desa Kohod Pakuhaji untuk Peningkatan Nilai Tambah dalam Pengolahan Limbah Kelapa sebagai Upaya Peningkatan Pendapatan Masyarakat. Jurnal Abdi Moestopo, 1 (01), 1922. https://doi.org/10.32509/am.v1i01.483 